Љиљана Марковић

Универзитет у Београду

Филолошки факултет
316.4

321.7

https://doi.org/10.18485/filkult.2016.1.ch2

\title{
Филологија и култура у доба модернизације
}

\section{Сажетак}

Филологија је кроз векове била синоним за одражавање културног напретка људског стваралаштва. Писани документи су служили да би дали увид у понекад оскудна, а у неким епохама и опширна и сложена сведочанства о труду и напретку. Међутим, управо у доба модернизације, Филологија има нову и кључну улогу да обједини своје традиционално дисциплинарно место са холистичком, транс- и интердисциплинарном улогом нове парадигме, која одговара лакој и ефикасној трансформацији традиционалне културе у „модернизовану”, чувајући истовремено виталну енергију традиционалног сектора и њеног основног скупа одлика које су у корелацији са различитим погледима на свет. Овај рад настоји да укаже на то да је Филологија, као комплексан скуп дисциплина, које су се преплитале и мешале током миленијума, управо она академска дисциплина која у најбољој могућој мери може да осветли брзе и вишеструке процесе који прожимају друштво у процесу „полетања” у модерно доба.

Кључне речи: филологија, култура, културна историја, модерни-зација

\section{Увод}

Култура, као друштвени феномен, подразумева скуп различитих „вредности, симбола, тумачења и перспектива на основу којих се народи међусобно разликују у модерним друштвима. Људи унутар одређене културе обично тумаче значење симбола, артефаката и понашања на исти или сличан начин. ${ }^{1}$

1 Banks, J.A., Banks, \& McGee, C. A. (1989). Multicultural education. Needham Heights, MA: 
Међутим, овакво поимање културе је измењено све учесталијом употребом дигиталних технологија, које у све већој мери укидају некадашње језичке и културолошке баријере међу народима, али и различитости које су чиниле културни идентитет нација. Феномен дигиталне глобализације је значајно допринео и хегемонији енглеског језика, који је на тај начин постао lingua franca у дигиталном окружењу. Студије које изучавају филологију и културу(е) у доба модернизације, морају пре свега размотрити велики утицај који дигиталне технологије имају на све области људског деловања, значај дигиталне хуманистике као научне дициплине која нуди оптималан спој модерних дигиталних технологија и хуманистичких и друштвених наука, као и концепте транскултуралности и транслингвалности.

\section{Филологија и култура у процесу глобализације и дигитализације}

Никола Тесла антиципира појаву Интернета и бежичних апарата још давне 1908. године у чланку Будућност бежичне уметности, објављеном у часопису Бежична телеграфија и телефонија и и најављује да је практична примена бежичних уређаја тек започела. И заиста, дигитално доба је у великој мери изменило начин на који комуницирамо, умножавајући средства комуникације и олакшавајући процес преношења порука на великим раздаљинама. Упркос хегемонији енглеског језика, потражња за радницима који поседују знање више страних језика никада није била већа на тржишту рада него данас. Наиме, како би се остварила успешна сарадња између различитих народа и нација, потребно је одлично познавање страних језика, као и мултикултурналне компетенције о чему ће у наставку рада бити речи. Уколико томе додамо чињеницу да се све чешће комуницира у виртуелном окружењу, као на пример путем и-мејла, потребно је савладати и основе виртуелне комуникације на одређеном страном језику. Факултети на којима се изучава филологија могу у најбољој могућој мери одговорити на изазове са којима се дипломци суочавају данас. Имајући у виду промене које

Allyn \& Bacon. 
је употреба дигиталних уређаја произвела, нешто традиционалнијој настави страних језика треба додати и смернице за комуникацију на страном језику у дигиталном окружењу.

Програми за машинско превођење, а пре свега слободно доступан Гугл Преводилац, нашли су назиглед широку примену у модерно доба. Међутим, лош квалитет превода текста путем оваквих програма само још једном сведочи о потреби за школовањем великог броја преводилаца и филолога, који поред језичких компетенција поседују и познавање култура одређених нација. Стога се у студијски програм филолошких факултета сврставају и садржаји о културама, обичајима и религији(ама) различитих земаља.

Процес глобализације и дигитализације чини студије културе наизглед готово непотребним, будући да англо-саксонска култура већ дуги низ година има примат на Интернету. Уз то се универзитети на којима се изучавају културе критикују од стране представника неолиберализма и капитализма „као неефикасани, бирократски настројени, и економски непродуктивни“2. Овакав закључак је у потпуности погрешан, будући да је за (економски) напредак сваке земље квалитетно образовање које подразумева и студије културе од суштинског значаја без обзира на свеопшти процес глобализације и хегемонију англо-саксонских културних образаца понашања. Наиме, употребом Интернета његови корисници долазе у додир са много већим бројем култура него што је то икада пре било могуће. Добро познавање различитих култура од великог је значаја како у приватном, тако и у пословном животу, јер је то основа сваке успешне комуникације.

Поред информатичке, информационе и дигиталне писмености, мултикултурна писменост представља једану од најважнијих вештина 21. века. Она се може дефинисати као „способност прихватања, поређења, разликовања и поштовања сличности и разлика у културним обрасцима понашања, уверењима и вредностима унутар и

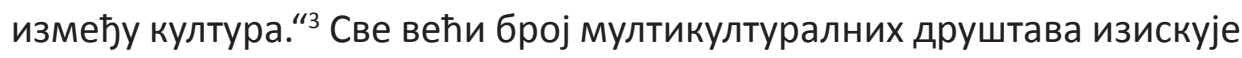

2 Välimaa, J., Ylijoki O. (2008). Cultural Perspectives on Higher Education. Springer. стр. 10.

3 Cordes, S. (2009). Broad horizons: The role of multimodal literacy in 21st Century library instruction. In World library and information congress: 75th IFLA general conference and council.ctp. 3. 
компетенције које ће омогућити неометани суживот различитих националних, етничких, верскихи културних група које живе на истом подручју. Међутим, Интернет је заправо креирао највећу виртуелну мултикултуралну заједницу која је икада постојала. У случају да корисници Интернета не поседују довољан ниво мултикултуралне писмености, они не могу савладати основе информационе писмености, односно нису у стању да одлуче да ли постоји потреба за информацијом, да пронађу, критички вреднују, и на адекватан начин употребе информације до којих дођу. Уколико имамо у виду да дигитална писменост „обухвата велики спектар сложених когнитивних, моторних, социолошких, и емоционалних вештина које су корисницима потребне (...) у дигиталном окружењу“4, јасно је да су мулитикултуралне компетенције саставни део исте.

\section{Транскултуралност, транслингвалност и дигитална хуманистика}

Немачка канцеларка Ангела Меркел 2010. године закључује да је „мултикулти“ концепт „у потпуности пропао“, те да га је потребно заменити новим, који ће омогућити бољу интеграцију великог броја миграната у немачко друштво. Наиме, са мигрантском кризом незапамћених размера постало је јасно да различите културе не могу коегзистирати на истом подручју као потпуно засебне, већ да ће у мултикултуралним друштвима увек доћи до уплива једне културе у другу. Ово ће неминовно водити потпуно измењеној културној мапи света, која ће у будућности обухватити бројне хибридне, транскултуралне заједнице. Са друге стране, чини се да физичке границе међу народима више и не постоје захваљујући Интернету и дигиталним технологијама.

Дигитална ера је довела до незапамћеног прожимања култура и језика, које је резултирало појавом феномена дигиталне транскултуралности. Сам концепт транскултуралности настаје још давне 1940. године, али са убрзаним развојем дигиталних

$4 \quad$ Eshet-Alkalai, Y. (2004). Digital literacy: A conceptual framework for survival skills in the digital era. Journal of Educational Multimedia and Hypermedia, 13(1), стр. 93. 
технологија доживљава нови процват. У чланку Транскултуралност - Загонетни облик култура данас, Волфганг Велш дефинише концепт транскултуралности као „последицу унутрашње диреренцијације и сложености модерних култура“". Он даље наглашава да су културе изузетно повезане и међусобно прожете, те да се више не могу изучавати као засебне целине (уколико су икада и могле бити тумачене на овај начин). Модерне информационе и комуникационе технологије су допринеле настанку нових, хибридних облика култура, које представљају мешавину различитих културних образаца са великим утицајем англо-саксонске културе.

Са друге стране, Интернет и дигиталне технологије су омогућиле и израду, постављање и слободан приступ садржајима на различитим језицима, те на тај начин подржавају дигиталну вишејезичност, али и својеврсну дигиталну транслингвалност. Клара Молина истиче да у настави „недостаје свест о транслингвалности као засебној комуникацијској компетенцији која се заснива на тумачењу порука“б, а Лаура Гонзалес у свом раду Мултимодалност, транслингвалност и реторичке студије жанра наглашава да нам „транслингвалност даје оквир за разумевање флуидности модалитета и језика" са поменутим, концепт транслингвалности је потребно размотрити у светлу филолошких наука и уврстити га као такав у редован план и програм факултета на којима се ове науке изучавају.

Транскултуралност и транслингвалност су уско повезани са дигиталном хуманистиком. У оквиру Манифеста дигиталне хуманистике 2.0 заступа се поступак мешања различитих жанрова и форми (енг. „mix :: match :: mash :: manifest“8) у дигиталном окружењу. Као стручњаци који вешто користе предности дигиталних технологија како би унапредили поље друштвених и хуманитичких наука,

5 Welsch, W. (1999). Transculturality: The puzzling form of cultures today. Spaces of culture: City, nation, world, 194-213.стр. 197.

6 Molina, C. (2011). Curricular insights into translingualism as a communicative competence. Journal of Language Teaching and Research, 2(6), 1244-1251.стр. 1245.

7 Gonzales, L. (2015). Multimodality, Translingualism, and Rhetorical Genre Studies. In Composition Forum (Vol. 31). Association of Teachers of Advanced Composition. Доступно на: http://files.eric.ed.gov/fulltext/EJ1061559.pdf, приступљено: 22.05.2016.

8 Schnapp, J., Presner, T., \& Lunenfeld, P. (2009). The digital humanities manifesto 2.0. Доступно на: http://www.humanitiesblast.com/manifesto/Manifesto_V2.pdf, приступљено: 22.05.2016. 
дигитални хуманисти и сами креирају садржаје транслингвалне и транскултуралне природе, које потом нуде Интернет корисницима.

\section{Филолошки факултети као високообразовне институције будућности}

Модерне дигиталне технологије омогућиле су повезивање људи различитих националности, што је резултирало високим степеном умрежености, који се у пословном окружењу огледа кроз бројне облике виртуелне сарадње (виртуелне фирме и виртуелни радници). Нови тренд у пословању могао би ускоро довести до укидања физичког простора фирми - канцеларија и изместити читаво пословање у виртуелно окружење. Осим тога, овакав вид пословања захтева и другачији профил радника. Читав образовни систем земаља широм света, а пре свега систем високог образовања, мора стога ускладити своје наставне планове и програме са захтевима на модерном тржишту рада, које је све више наклоњено виртуелној организацији рада. Велика потражња за стручњацима у области информационих технологија јасно сведочи о томе. Поред тога, треба имати у виду да ће се ова промена у пословању одразити не само на занимања из области информационих технологија, већ и на све друге професије, међу којима су и филолози. Филолози тако током студија морају савладати основе информатичке, информационе, дигиталне и мултикултуралне писмености како би своја знања успешно применили у пословном окружењу.

Филолошки факултет Универзитета у Београду је у потпуности посвећен изучавању 34 језика, књижевности и култура и представља највећу и најзначајнију високообразовну институцију ове врсте у Србији, као и једну од највећих у југоисточној Европи. Наставни план и програм факултета је усклађен са потребама не само српског, већ и европског тржишта рада, будући да је сачињен на основу принципа за које се залаже Европски простор високог образовања (ЕНЕA), као и смерница које су прописане у оквиру Заједничког европског оквира за живе језике Савета Европе (енг. Common European Framework of Reference for Languages). 
Филологија културе

Са циљем да спремно одговори на брзе и учестале промене које су проузроковале модерне дигиталне технологије и све већи степен глобализације, Филолошки факултет је понудио студијски програм Језик, књижевност, култура на свим нивоима студија. Премда студенти на вишим нивоима студија имају опцију да се определе за основни модул, програм нуди (интер-)мултидисциплинарност, односно изучавање више научних области кроз призму филолошких наука. На овај начин, образујемо новипрофил филолога који јеспреман да се констатно усавршава и надограђује своја знања и вештине. По завршетку студија, дипломирани филолози су оспособљени за процес целоживотног учења, имајући стално у виду да се ниједна професија више не може посматрати независно од других.

\section{Закључак}

Све учесталија употреба Интернета и дигиталних технологија омогућила је ненадмашан ниво повезаности људи широм света, као и њихово активно учешће у креирању садржаја и размени различитих идеја, мишљења, информација и знања. Филологија и култура, као области које чувају од заборава и у великој мери унапређују општеприхваћене цивилизацијске вредности, неминовно су претрпеле измене, не изгубивши притом ништа од пређашњег значаја, већ само надограђујући вековима неговане основе. Филолошки факултет Универзитета у Београду нуди простор за изучавање великог броја страних језика, књижевности и култура, као и простор за њихова прожимања, при чему се јасно залаже за модернизацију наставе и истраживачких активности из области филологије и културе.

\section{Литература}

Banks, J.A., Banks, \& McGee, C. A. (1989). Multicultural education. Needham Heights, MA: Allyn \& Bacon.

Cordes, S. (2009). Broad horizons: The role of multimodal literacy in 21st Century library instruction. In World library and information congress: 75th IFLA general conference and council. 
Eshet-Alkalai, Y. (2004). Digital literacy: A conceptual framework for survival skills in the digital era. Journal of Educational Multimedia and Hypermedia, 13(1).

Gonzales, L. (2015). Multimodality, Translingualism, and Rhetorical Genre Studies. In Composition Forum (Vol. 31). Association of Teachers of Advanced Composition. Доступно на: http://files.eric.ed.gov/fulltext/EJ1061559.pdf, приступљено: 22.05.2016.

Molina, C. (2011). Curricular insights into translingualism as a communicative competence. Journal of Language Teaching and Research, 2(6), 1244-1251.

Schnapp, J., Presner, T., \& Lunenfeld, P. (2009). The digital humanities manifesto 2.0. Доступно на: http://www.humanitiesblast.com/manifesto/Manifesto_V2.pdf, приступљено: 22.05.2016.

Välimaa, J., Ylijoki O. (2008). Cultural Perspectives on Higher Education. Springer.

Welsch, W. (1999). Transculturality: The puzzling form of cultures today. Spaces of culture: City, nation, world, 194-213.

\author{
Ljiljana Marković \\ University of Belgrade \\ Faculty of Philology
}

\title{
PHILOLOGY AND CULTURE IN MODERNIZATION
}

\section{Summary}

Philology has been synonymous with mirroring the cultural advancement of human creativity throughout the ages. Written documents served to provide scarce, while in some epochs ample and complex testimony, of effort and progress. However, it is precisely in the age of Modernization, that Philology has the new and crucial role to perform in uniting its traditional identity discipline role with a holistic, trans- and interdisciplinary role of a new paradigm, congenial to a smooth and efficient transformation of a traditional culture into a "modernized" one, while preserving the vital energy of the the traditional sector and its fundamental set of world-view attributes. This paper purports to demonstrate that Philology is, as a complex set of disciplines, intertwined and blended over the millennia, precisely the academic discipline best suited to enlighten the rapid and manifold processes that permeate a society in the process of "take-off" into modern age.

Key words: Philology, Culture, Cultural History, Modernization 